\title{
Inorganic carbon and nutrient fluxes on the Arctic Shelf
}

\author{
Miroslav Nitishinsky a,b, Leif G. Anderson ${ }^{\mathrm{a}, *}$, Jens A. Hölemann ${ }^{\mathrm{c}}$ \\ ${ }^{a}$ Department of Chemistry, Göteborg University, SE-412 96 Göteborg, Sweden \\ ${ }^{\mathrm{b}}$ Arctic and Antarctic Research Institute, 199397, 38 Beringa Str., St. Petersburg, Russia \\ ${ }^{\mathrm{c}}$ Alfred Wegener Institute for Polar and Marine Research, Columbusstrasse, D-27568, Bremerhaven, Germany
}

Received 17 May 2005; received in revised form 9 January 2007; accepted 17 January 2007

Available online 4 February 2007

\begin{abstract}
Historic data from the Russian-American Hydrochemical Atlas of Arctic Ocean together with data from the TRANSDRIFT II 1994 and TUNDRA 1994 cruises have been used to assess the spatial and inter-annual variability of carbon and nutrient fluxes, as well as air-sea $\mathrm{CO}_{2}$ exchange in the Laptev and western East Siberian Seas during the summer season. Budget computations using summer data of dissolved inorganic phosphate (DIP), dissolved inorganic nitrogen (DIN) and dissolved inorganic carbon (DIC) gives that the Laptev Sea shelf is a net sink of DIP and DIN of $2.5 \times 10^{6}, 23.2 \times 10^{6} \mathrm{mold}^{-1}$, respectively, while it is a net source of DIC (excluding air-sea exchange) of $1249 \times 10^{6} \mathrm{~mol} \mathrm{~d}^{-1}$. In the East Siberian Seas the budget computations give $0.5 \times 10^{6},-11.4 \times 10^{6}$ and $-173 \times 10^{6} \mathrm{~mol} \mathrm{~d}^{-1}$ (minus being a sink) for DIP, DIN, and DIC, respectively. In summers, the Laptev Sea Shelf is net autotrophic while the East-Siberian Sea Shelf is net heterotrophic, and both systems are weak net denitrifying. The Laptev Sea Shelf takes up $2.1 \mathrm{mmol} \mathrm{CO}_{2} \mathrm{~m}^{-2} \mathrm{~d}^{-1}$ from atmosphere, whereas the western part of the East-Siberian Sea Shelf loose $0.3 \mathrm{mmol}$ $\mathrm{CO}_{2} \mathrm{~m}^{-2} \mathrm{~d}^{-1}$ to the atmosphere. The variability of DIP, DIN and DIC fluxes during summer in the different regions of the Laptev and East Siberian Seas depends on bottom topography, river runoff, exchange with surrounding seas and wind field.
\end{abstract}

(C) 2007 Elsevier Ltd. All rights reserved.

Keywords: Dissolved inorganic carbon; Nutrients; $\mathrm{CO}_{2}$ exchange; Spatial and temporal variability; Fluxes; Arctic Shelf; Laptev Sea; East-Siberian Sea

\section{Introduction}

Climate change is a reality and the Arctic region is where it was first manifested. The summer sea ice cover has decreased at an average rate of about $3 \%$ per decade during the 1980s and 1990s (e.g., Johannessen et al., 1995; Cavalieri et al., 1997), the sea ice volume shows a trend of $-4 \%$ per decade

\footnotetext{
*Corresponding author. Tel.: + 46317722774 ; fax: +46317722785 .

E-mail address: leifand@chem.gu.se (L.G. Anderson).
}

(e.g., Rothrock and Zhang, 2005), and the average annual discharge of fresh water from the six largest Eurasian rivers to the Arctic Ocean increased by 7\% from 1936 to 1999 (Peterson et al., 2002). All these changes have an impact on the marine climate and also on the cycling of nutrients and carbon, both directly and also through changes in the conditions affecting biological transformations. The Siberian shelf seas, like the Laptev Sea and East-Siberian Sea, are especially influenced by these changes as they experience seasonal ice coverage as well as receive large discharge volumes. 
With one of the driving forces of climate change being the increasing load of $\mathrm{CO}_{2}$ to the atmosphere it is essential to assess feedbacks to this load. About $40 \%$ of the emitted anthropogenic $\mathrm{CO}_{2}$ is taken up by the ocean, but this number is still uncertain and how changes in climate might affect it is only rudimentary known. Changes in the seasonal ice cover, timing as well as magnitude, within the Arctic Ocean and in the magnitude of the discharge to the Arctic Ocean will likely affect the air-sea $\mathrm{CO}_{2}$ flux substantially. One of the key questions related to possible modifications in such fluxes by climate change is the strength of natural variability.

This work evaluates historic data to assess variability in the strength of biological transformation as well as air-sea $\mathrm{CO}_{2}$ flux in the Laptev and East-Siberian Seas Shelf. A two-layer box model is applied assuming steady state, but with the data coverage only allowing us to perform the computations for the summer season when both sea ice melt and runoff has contributed substantially to freshening of mainly the surface layer. However, the residence time of the surface water has been estimated to about 3 years using ${ }^{18} \mathrm{O}$ (Schlosser et al., 1994) and, therefore, the computed exchange of seawater with the surroundings should be fairly robust.

\section{Study area}

The Laptev and East-Siberian seas are located in the middle of the Siberian shelf (Fig. 1). Geogra- phically, the largest parts of these seas are located over the shallow shelf, and the smallest parts occupy the continental slope and deep basin. There are a few underwater valleys, highlands and banks on the shelf. The mean depth of the Laptev and EastSiberian seas shelf is less than $50 \mathrm{~m}$. The bottom topography influences the water circulation (Ipatov and Yakovlev, 1999; Baskakov et al., 1999) with the bottom depressions characterized by high sedimentation rates (Thiede et al., 1999) and stagnant water conditions (Pivovarov and Smagin, 1995).

The Laptev and East-Siberian seas are considered as the most harsh shelf seas of the Arctic Ocean because of the high latitude and the remoteness from the Atlantic and Pacific Oceans (Danilov et al., 1994). Air temperatures over the seas are characterized by great seasonal fluctuations (The Atlas of the Arctic, 1985). From October to June, the Laptev and East-Siberian seas are covered by sea ice of various thicknesses and ages, but with a more or less permanent flaw lead polynya in the Laptev Sea. The seas are regions with one of the highest net ice production rates in the Arctic Ocean (Zakharov, 1996). Ice conditions influences the physical and chemical properties of water masses and they are an important component of the Arctic seas ecosystem (Nikiforov and Shpaicher, 1980; Rusanov et al., 1979; Thiede et al., 1999). Ice melting begins at June-July and in August-September there are large areas of open water. The average volume of sea ice melt for the Laptev Sea is approximately $800 \times 10^{9} \mathrm{~m}^{3}$ per summer (Zakharov, 1996).

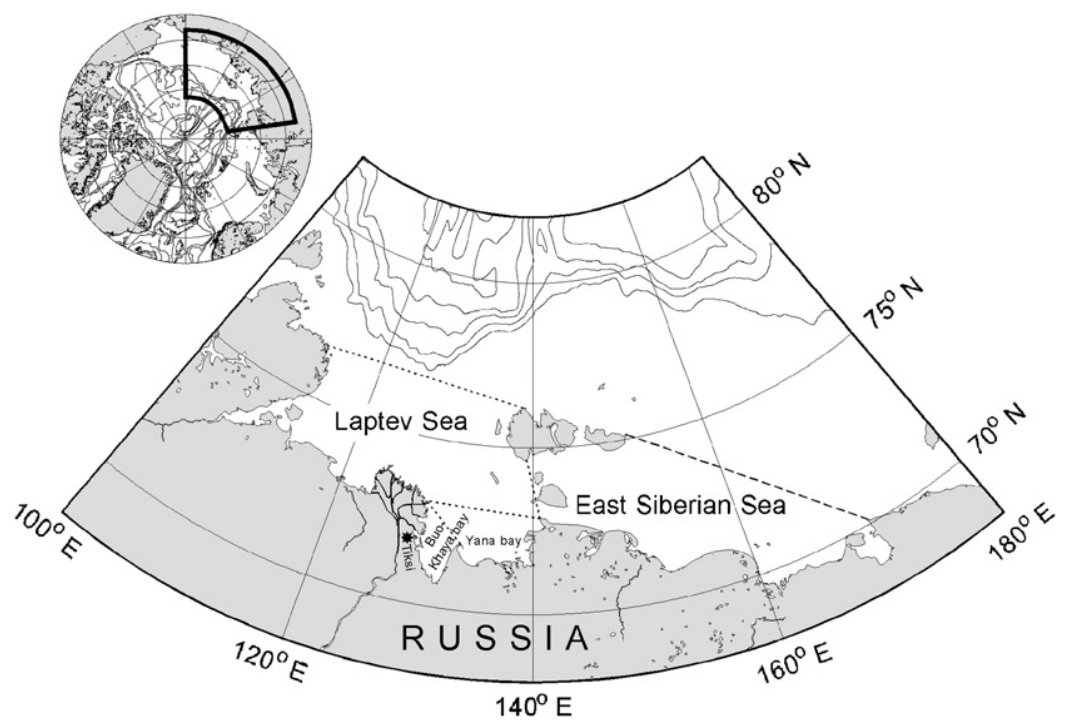

Fig. 1. Map of the Laptev and East-Siberian Seas with the borders of the regions discussed indicated by dotted lines. 
Many small and some large rivers enter into the Laptev and East-Siberian seas. The Lena River is the largest, with an annual discharge of about $525 \times 10^{9} \mathrm{~m}^{3}$. The annual inflow of fresh water runoff into the Laptev Sea is approximately $745 \times 10^{9} \mathrm{~m}^{3}$ and about $250 \times 10^{9} \mathrm{~m}^{3}$ into the EastSiberian Sea (Gordeev et al., 1999). There is a large seasonal variability with approximately $90 \%$ of the total annual runoff from June till September (Bryzgalo and Ivanov, 2000).

The oceanic circulation pattern in these seas is complex and variable, a result of the temporal fluctuations of river discharge and wind pattern. Changes in the prevailing wind direction lead to a restructure of the water circulation pattern, in accordance with water density, seabed topography and carioles effect. The mean velocities of the currents are very low (about $2 \mathrm{~cm} \mathrm{~s}^{-1}$ ) with some calm zones (Ipatov and Yakovlev, 1999; Baskakov et al., 1999). However, there is a general flow along the coast towards the east, from the Laptev Sea through the East Siberian Sea and into the Chukchi Sea.

The water column can be divided into three vertical layers: surface, intermediate, and bottom, comprising separate water masses. These water masses have different temperature, chemical and biological properties. Fig. 2a shows a typical salinity profile from the Buor-Khaya bay and Fig. $2 b$ shows the vertical scatter of salinity in the western East Siberian Sea. The more complex view of the Laptev Sea is illustrated in Fig. 2c.

The nutrient distributions and variability are related to biological cycles, river inflow, water mass advection from the Arctic Basin and adjacent seas, as well as hydrological conditions. More than 119 species of phytoplankton have been found in the Laptev and East-Siberian seas, dominated by diatom assemblages (Tuschling, 2000). Primary production is one of the main characteristics of the phytoplankton lifecycle and it ranges from 75 to $640 \mathrm{~m} \mathrm{C} \mathrm{C}^{-3}$ for $24 \mathrm{~h}$ in the Buor-Khaya Gulf (Tuschling, 2000). Within the Laptev Sea the observed primary production over $24 \mathrm{~h}$ varies from 40 to $90 \mathrm{mg} \mathrm{C} \mathrm{m}^{-3}$ in the East, from 24 to $41 \mathrm{mg} \mathrm{C} \mathrm{m}^{-3}$ in the West, and from 115 to $154 \mathrm{mg} \mathrm{C} \mathrm{m}^{-3}$ in the North near the continental slope and ice edge (Sorokin et al., 1993; Gleitz and Grossmann, 1997; Tuschling, 2000). Phytoplankton biomass values within the Laptev Sea vary between 200 and $1500 \mathrm{mg} \mathrm{m}^{-3}$ (Gleitz and Grossmann, 1997; Tuschling, 2000).
The coastlines of the Laptev and East-Siberian seas are almost uninhabited. There are a few small settlements, with a total population not exceeding 10000 people. The catchments area of the rivers is located in the territory of the Yakutia (Saha) republic, in which a few towns (Yakutsk, Lensk, Tiksi) are located along the middle and upper Lena River, but the population density is low.

Four regions, Buor-Khaya Bay, Buor-Khaya and Yana Bays, Laptev Sea Self and western part of East-Siberian Sea Shelf, were selected in this study of the Siberian shelf system (Fig. 1). Historic data from these regions allow an assessment of the temporal and spatial variability in carbon and nutrient fluxes. The meteorology, hydrology and chemistry condition of these regions are given in Table 1, and with the average concentrations of salinity and chemistry in the different regions of the Laptev Sea Shelf in Table 2.

\section{Material and methods}

\subsection{Data}

The data used in this work is from the RussianAmerican Hydrochemical Atlas of Arctic Ocean (Colony et al., 2002), complemented by data from the specific cruises TRANSDRIFT II 1994 (Thiede et al., 1999) and TUNDRA 1994 (Olsson and Anderson, 1997). Average data of relevant parameters as observed in some regions of the Arctic Shelves in summer 1994 are presented in Table 1. The data from the TUNDRA 1994 and TRANSDRIFT II 1994 expedition includes the most parameters and where thus were used to study the spatial variability. The Russian-American Hydrochemical Atlas of Arctic Ocean (Colony et al., 2002) covers a long time period (but without any DIC values) and was used to study the temporal variability (Table 2). For the study of both the temporal and spatial variability, average salinity of the bottom and surface layers in the Laptev Sea Shelf, Buor-Khaya and Yana bays area and BuorKhaya bay were collected from the AARI Data Base. The locations of the oceanographic stations are showed in Fig. 3.

Annual summer data (July-September) of evaporation and precipitation from The Atlas of the Arctic (1985) and annual volumes of river runoff and ground water for summer (July-September) (Gordeev et al., 1999; Bryzgalo and Ivanov, 2000) was used to compute carbon and nitrogen fluxes. 
a

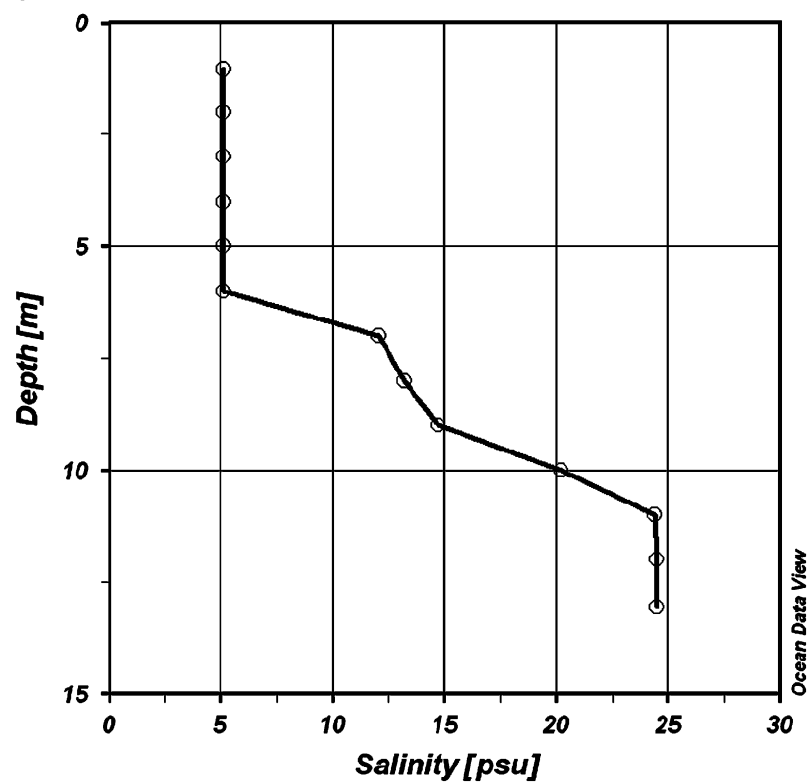

b

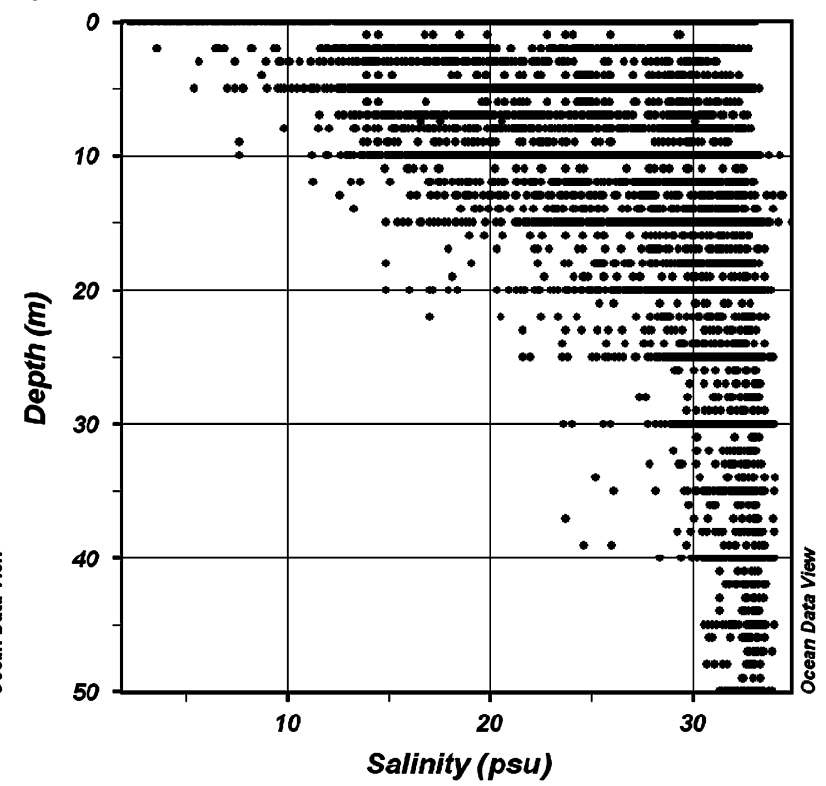

C

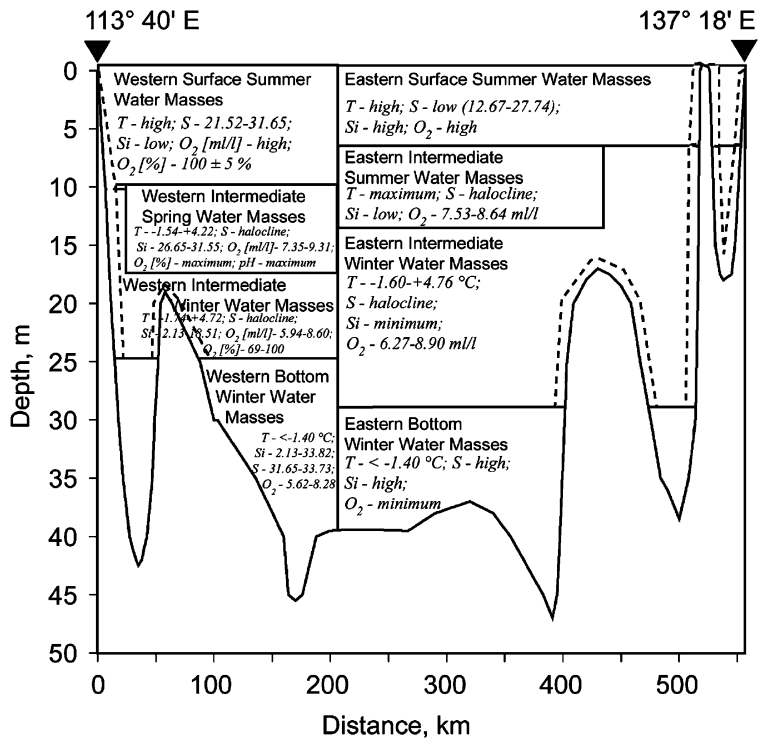

Fig. 2. A typical salinity profile in the Buor-Khaya Bay $\left(130.5^{\circ} \mathrm{E}, 72.2^{\circ} \mathrm{N}\right.$, Sep $/ 16 / 1994$, TRANSDRIFT-II) (a), a scatter plot of the vertical salinity distribution in the western East-Siberian Sea Shelf (Archive of AARI) (b), and water column structure along a transect along $75^{\circ} 30^{\prime} \mathrm{N}$ across the Laptev Sea in summer (c) (Nitishinsky et al., 2003).

\subsection{Methods}

A detailed description of the methodology of budget studies in coastal systems is described at the website of the International LOICZ (Land-Ocean Interaction Coastal Zone) programme (http:// www.loicz.org) and in David et al. (2000) and Gordon et al. (1996). In this work the two-layered
LOICZ model (Gordon et al., 1996) was applied to calculate nutrient and carbon fluxes, with the model constrained by water and salt budgets (Fig. 4).

The model is based on that: (i) A freshwater inflow $\left(V_{R}\right)$ (equalling the sum of river runoff $V_{Q}$, ground water discharge $V_{G}$, precipitations $V_{P}$, minus evaporation $V_{E}$ ) is added to the surface layer. (ii) $\mathrm{A}$ net inflow of seawater $\left(V_{D}\right)$ enters the 
Table 1

Areas, average depths, water fluxes and concentration of chemistry parameters in the Laptev and East Siberian Seas shelf systems in summer 1994

\begin{tabular}{|c|c|c|c|c|}
\hline & Buor-Khaya Bay & $\begin{array}{l}\text { Buor-Khaya and } \\
\text { Yana Bays }\end{array}$ & $\begin{array}{l}\text { The Laptev Sea } \\
\text { Shelf }\end{array}$ & $\begin{array}{l}\text { The western part of the } \\
\text { East-Siberian Sea Shelf }\end{array}$ \\
\hline Area, $\mathrm{km}^{2 \mathrm{a}}$ & 15,535 & 46,605 & 475,000 & 393,000 \\
\hline Depth, $\mathrm{m}^{\mathrm{a}}$ & 10 & 20 & 50 & 25 \\
\hline Precipitation, $10^{6} \mathrm{~m}^{3} \mathrm{~d}^{-1 \mathrm{a}}$ & 9.5 & 28.5 & 65 & 53.8 \\
\hline Evaporation, $10^{6} \mathrm{~m}^{3} \mathrm{~d}^{-1 \mathrm{a}}$ & 3.2 & 9.5 & 260 & 215 \\
\hline River discharge, $10^{6} \mathrm{~m}^{3} \mathrm{~d}^{-1 \mathrm{~b}}$ & 1240 & 1251 & 1800 & 978 \\
\hline Groundwater, $10^{6} \mathrm{~m}^{3} \mathrm{~d}^{-1 \mathrm{~b}}$ & 16 & 17 & 39 & 63 \\
\hline Surface salinity ${ }^{\mathrm{c}}$ & 6.03 & 8.87 & 21.56 & $19.01^{\mathrm{e}}$ \\
\hline Deep salinity ${ }^{\mathrm{c}}$ & 18.62 & 20.46 & 33.19 & $29.88^{\mathrm{e}}$ \\
\hline Surface phosphate, $\mu \mathrm{mol} \mathrm{kg}{ }^{-1 \mathrm{c}}$ & 0.08 & 0.09 & 0.11 & $0.94^{\mathrm{e}}$ \\
\hline Deep phosphate, $\mu \mathrm{mol} \mathrm{kg}{ }^{-1 \mathrm{c}}$ & 0.29 & 0.44 & 0.98 & $1.97^{\mathrm{e}}$ \\
\hline Surface nitrate, $\mu \mathrm{mol} \mathrm{\textrm {kg } ^ { - 1 \mathrm { c } }}$ & 0.1 & 0.1 & 0.3 & $0.4^{\mathrm{e}}$ \\
\hline Deep nitrate, $\mu \mathrm{mol} \mathrm{kg}-1 \mathrm{c}$ & 3.7 & 6.0 & 6.4 & $1.8^{\mathrm{e}}$ \\
\hline Surface DIC, $\mu \mathrm{mol} \mathrm{kg}{ }^{-1 \mathrm{c}}$ & 958 & 1082 & 1893 & 1431 \\
\hline Deep DIC, $\mu \mathrm{mol} \mathrm{kg}-1 \mathrm{c}$ & 1654 & 1732 & 2181 & 2004 \\
\hline DIP of river water, $\mu \mathrm{mol} \mathrm{kg}-1 \mathrm{~b}$ & $0.58^{\mathrm{f}}$ & $0.58^{\mathrm{f}}$ & 0.30 & 0.29 \\
\hline DIN of river water, $\mu \mathrm{mol} / \mathrm{kg}^{\mathrm{b}}$ & $14.62^{\mathrm{f}}$ & $14.62^{\mathrm{f}}$ & 1.40 & 3.10 \\
\hline 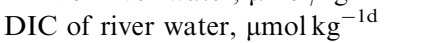 & 610 & 610 & 610 & 610 \\
\hline DIP of ground water, $\mu \mathrm{mol} \mathrm{kg}-1 \mathrm{~b}$ & $1.48^{\mathrm{f}}$ & $1.48^{\mathrm{f}}$ & 0.50 & 0.72 \\
\hline DIN of ground water, $\mu \mathrm{mol} \mathrm{kg}-1 \mathrm{~b}$ & $33.92^{\mathrm{f}}$ & $33.92^{\mathrm{f}}$ & 4.40 & 8.93 \\
\hline DIC of ground water, $\mu \mathrm{mol} \mathrm{kg}-1 \mathrm{~d}$ & 610 & 610 & 610 & 610 \\
\hline
\end{tabular}

${ }^{\mathrm{a}}$ The Atlas of the Arctic (1985).

${ }^{\mathrm{b}}$ Gordeev et al. (1999); Bryzgalo and Ivanov (2000).

${ }^{\mathrm{c}}$ TUNDRA 1994 (Olsson and Anderson, 1997) and TRANSDRIFT II (Thiede et al., 1999) expeditions.

${ }^{\mathrm{d} O l s s o n}$ and Anderson (1997).

${ }^{\mathrm{e}}$ The average concentration of all observation period, Hydrochemistry atlas of Arctic Ocean (Colony, et al. 2002) and AARI database.

${ }_{\mathrm{f}}^{\mathrm{f}}$ Annual report of Russia river discharge from 1951 till 1990.

deep layer across the open boundary to the outside ocean. (iii) A corresponding flow $\left(V_{D^{\prime}}\right)$ into the surface layer, and (iv) a flow across the open boundary out to the outside ocean from the surface layer $\left(V_{S}\right)$ that equals the inflows $V_{R}+V_{D^{\prime}}$ to this layer. Finally, the salt budget of the two layers is balanced by a vertical mixing flux $\left(V_{Z}\right)$ between the surface and deep layers. The boundary between the two layers are chosen according to the hydrological conditions, with the thickness of the surface layer from the sea surface down to the pycnocline and the deep layer is from the pycnocline to the bottom. Any salt flux from erosion of the coastline is neglected.

Using these conditions we end up with the following equations. The water budget of the surface layer equals:

$V_{Q}+V_{G}+\left(V_{P}-V_{E}\right)+V_{D^{\prime}}-V_{S}=0$,

while that of the deep layer equals:

$V_{D}-V_{D^{\prime}}=0$.
The vertical mixing $\left(V_{Z}\right)$ is not included in the water budgets as it has the same in and out flux for both layers. The salt budget for the surface layer is

$$
\begin{aligned}
V_{Q} S_{Q} & +V_{G} S_{G}+\left(V_{P}-V_{E}\right) S_{P}+V_{D^{\prime}} S_{\text {Shelf }-D} \\
& -V_{S} S_{\text {Shelf }-S}+V_{Z}\left(S_{\text {Shelf }-D}-S_{\text {Shelf }-S}\right)=0,
\end{aligned}
$$

where $S_{\text {Shelf-S }}$ is the salinity of the surface layer in the system, $S_{\text {Shelf }-D}$ the salinity of the deep layer, and the other salinities are denoted in accordance with those of the volume fluxes. The salt budget of the bottom layer equals:

$$
\begin{aligned}
& V_{D} S_{\text {Ocean-D }}-V_{D^{\prime}} S_{\text {Shelf }-D} \\
& +V_{Z}\left(S_{\text {Shelf }-D}-S_{\text {Shelf }-S}\right)=0 .
\end{aligned}
$$

All the salinities are known from observations, as are the fresh water influxes of Eq. (5).

$V_{R}=V_{Q}+V_{G}+\left(V_{P}-V_{E}\right)$.

Combining Eqs. (1) and (5) gives Eq. (6).

$V_{S}=V_{R}+V_{D^{\prime}}$ 
Table 2

Average concentrations of salinity, phosphate, nitrate and carbon (dissolved inorganic) during summer in the different regions of the Laptev Sea Shelf

\begin{tabular}{|c|c|c|c|c|c|c|c|c|}
\hline \multirow[t]{2}{*}{ Years } & \multicolumn{4}{|l|}{ Surface } & \multicolumn{4}{|l|}{ Deep } \\
\hline & $\begin{array}{l}\text { Salinity } \\
\text { (psu) }\end{array}$ & $\begin{array}{l}\text { Phosphate } \\
\left(\mu \mathrm{mol} \mathrm{kg}{ }^{-1}\right)\end{array}$ & $\begin{array}{l}\text { Nitrate } \\
\left(\mu \mathrm{mol} \mathrm{kg}{ }^{-1}\right)\end{array}$ & $\begin{array}{l}\text { Carbon } \\
\left(\mu \mathrm{mol} \mathrm{kg}{ }^{-1}\right)\end{array}$ & $\begin{array}{l}\text { Salinity } \\
\text { (psu) }\end{array}$ & $\begin{array}{l}\text { Phosphate } \\
\left(\mu \mathrm{mol} \mathrm{kg}{ }^{-1}\right)\end{array}$ & $\begin{array}{l}\text { Nitrate } \\
\left(\mu \mathrm{mol} \mathrm{kg}{ }^{-1}\right)\end{array}$ & $\begin{array}{l}\text { Carbon } \\
\left(\mu \mathrm{mol} \mathrm{kg}{ }^{-1}\right)\end{array}$ \\
\hline \multicolumn{9}{|c|}{ The Laptev Sea Shelf } \\
\hline 1963 & 25.15 & 0.25 & 1.01 & - & 33.32 & 0.75 & 4.30 & - \\
\hline 1973 & 24.61 & 0.18 & - & - & 33.37 & 0.50 & - & - \\
\hline 1974 & 18.42 & 0.18 & - & - & 33.57 & 0.75 & - & - \\
\hline 1975 & 22.79 & 0.25 & - & - & 32.57 & 0.98 & - & - \\
\hline 1985 & 21.41 & 0.09 & 0.21 & - & 33.06 & 1.20 & 7.65 & - \\
\hline 1993 & 20.36 & 0.13 & - & - & 32.61 & 0.84 & - & - \\
\hline 1994 & 21.56 & 0.11 & 0.30 & 1839 & 33.19 & 0.98 & 6.40 & 2181 \\
\hline 1998 & 21.13 & 0.22 & - & - & 32.86 & 1.05 & - & - \\
\hline 1999 & 19.94 & 0.19 & - & - & 33.11 & 1.38 & - & - \\
\hline \multicolumn{9}{|c|}{ The Buor-Khaya and Yana bays } \\
\hline 1963 & 10.04 & 0.20 & 4.39 & - & 19.76 & 1.60 & 4.85 & - \\
\hline 1969 & 11.61 & 0.19 & - & - & 27.01 & 0.68 & - & - \\
\hline 1971 & 13.10 & 0.05 & - & - & 28.10 & 0.31 & - & - \\
\hline 1972 & 7.94 & 0.32 & - & - & 27.52 & 0.97 & - & - \\
\hline 1973 & 9.94 & 0.32 & - & - & 27.52 & 0.25 & - & - \\
\hline 1974 & 11.31 & 0.32 & - & - & 29.18 & 0.55 & - & - \\
\hline 1975 & 7.29 & 0.23 & - & - & 30.16 & 0.87 & - & - \\
\hline 1993 & 7.36 & 0.05 & - & - & 28.50 & 0.35 & - & - \\
\hline 1994 & 8.87 & 0.09 & 0.10 & 1086 & 20.46 & 0.45 & 6.05 & 2732 \\
\hline \multicolumn{9}{|c|}{ The Buor-Khaya bay } \\
\hline 1970 & 2.85 & 0.21 & - & - & 20.86 & 0.52 & - & - \\
\hline 1971 & 6.28 & 0.32 & - & - & 21.40 & 0.41 & - & - \\
\hline 1972 & 5.25 & 0.32 & - & - & 10.04 & 0.97 & - & - \\
\hline 1973 & 2.90 & 0.32 & - & - & 17.79 & 0.48 & - & - \\
\hline 1974 & 7.79 & 0.39 & - & - & 21.73 & 0.55 & - & - \\
\hline 1975 & 6.13 & 0.28 & - & - & 20.28 & 0.68 & - & - \\
\hline 1984 & 2.85 & 0.07 & 2.00 & - & 22.53 & 0.36 & 5.07 & - \\
\hline 1985 & 3.31 & 0.06 & 1.29 & - & 21.15 & 0.29 & 3.50 & - \\
\hline 1993 & 4.84 & 0.05 & - & - & 25.07 & 0.27 & - & - \\
\hline 1994 & 6.03 & 0.08 & 0.10 & 958 & 18.20 & 0.30 & 5.00 & 1655 \\
\hline 1995 & 9.06 & 0.31 & - & - & 27.69 & 0.86 & - & - \\
\hline 1996 & 3.56 & 0.28 & - & - & 26.23 & 0.73 & - & - \\
\hline 1998 & 8.22 & 0.15 & - & - & 21.87 & 0.48 & - & - \\
\hline 1999 & 10.99 & 0.18 & - & - & 27.76 & 0.84 & - & - \\
\hline
\end{tabular}

In the above equations there are two unknowns, $V_{D^{\prime}}$ and $V_{Z}$, which can be expressed in known parameters according to Eqs. (7) and (8).

$V_{D}=\frac{V_{R} S_{\text {Shelf }-S}-V_{Q} S_{Q}-V_{G} S_{G}}{S_{\text {Ocean-D }}-S_{\text {Shelf }-S}}$

and

$V_{Z}=V_{D} \frac{S_{\text {Ocean }-D}-S_{\text {Shelf }-D}}{S_{\text {Shelf }-D}-S_{\text {Shelf }-S}}$.

The above equations assume conservation of mass and salt, i.e. steady state.
Having the two unknowns from Eqs. (7) and (8) makes it possible to compute budgets of any conservative constituent. The aim of this contribution is to calculate budgets of dissolved inorganic phosphorus (phosphate) (DIP), dissolved inorganic nitrogen (sum of nitrate, nitrite and ammonia) (DIN) and dissolved inorganic carbon (DIC). Nitrite and ammonia concentrations are normally low in our study area and we thus only use nitrate to compute the DIN budget. DIP, DIN and DIC are "non-conservative" constituents, making budgets of these depend on different processes active in the system. For example, phytoplankton controls 
a

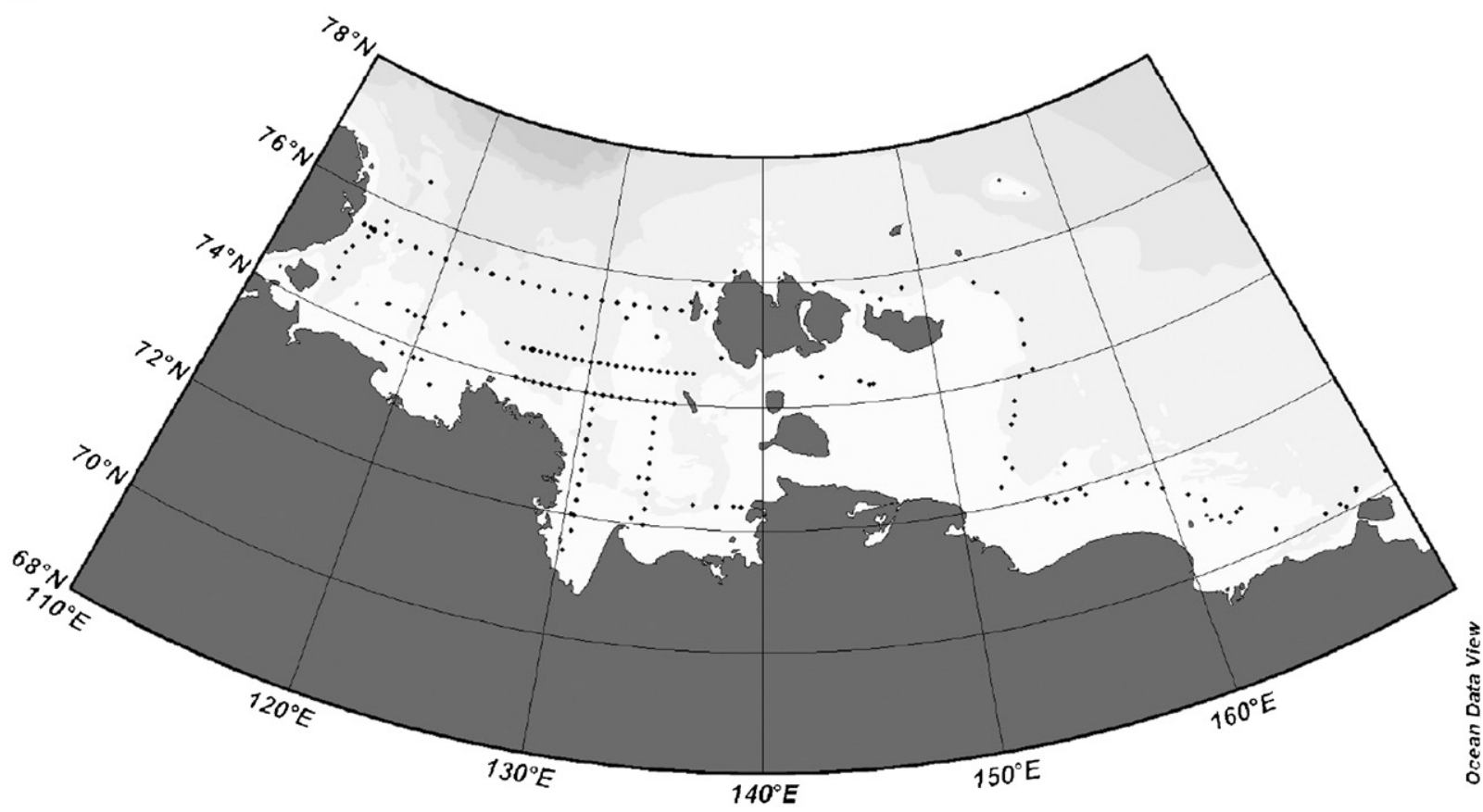

b

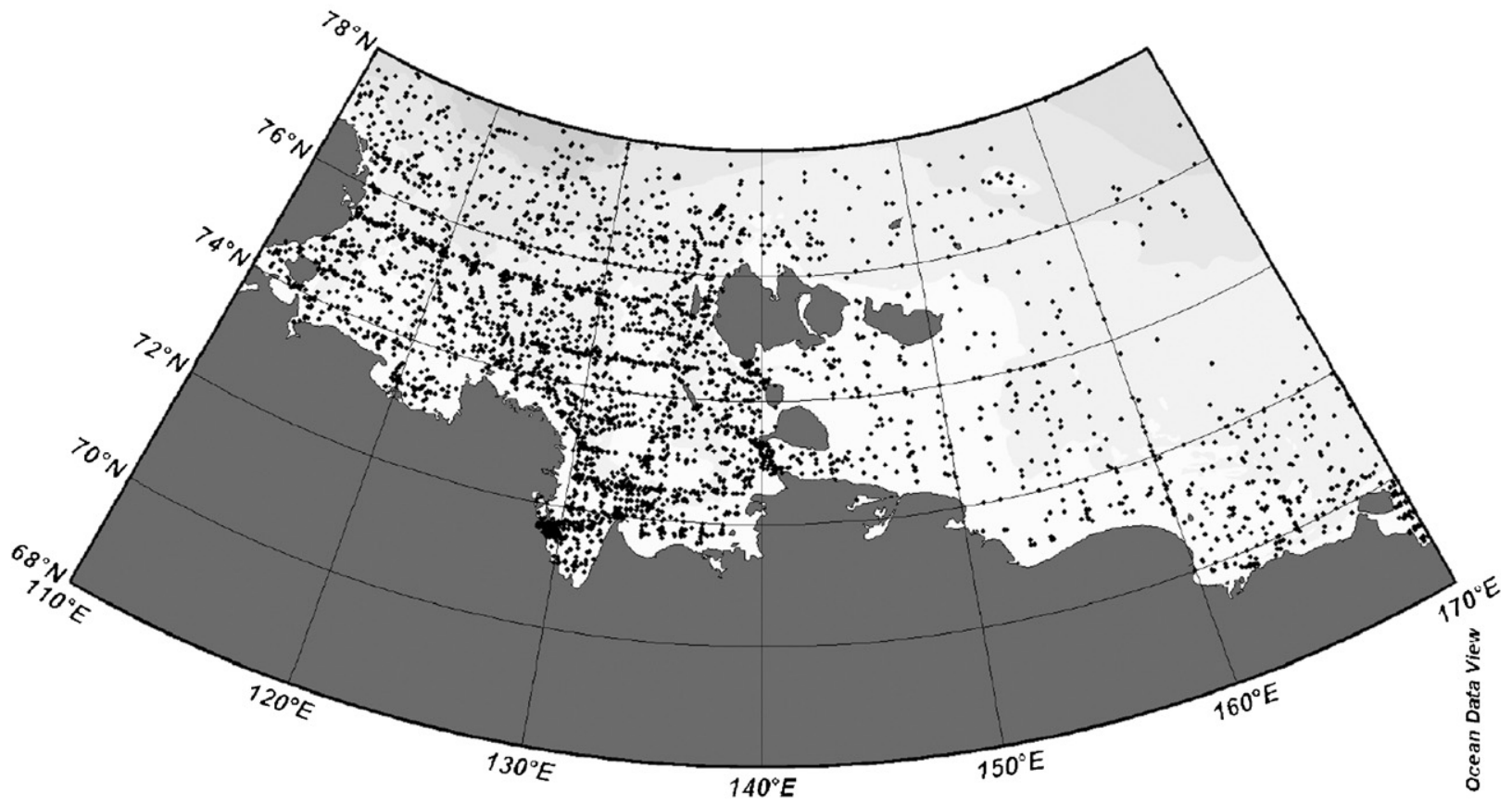

Fig. 3. Oceanographic station locations during (a) the TUNDRA 1994 (Olsson and Anderson, 1997) and TRANSDRIFT II (Thiede et al., 1999) expeditions in the summer of 1994 and (b) from the Russian-American Hydrochemical Atlas of Arctic Ocean (Colony et al., 2002).

phosphate concentration during summer, where phosphate concentrations can be transformed into either organic or total phosphorus. Nitrogen and carbon are also "non-conservative" but with more complex biochemical cycles, as they can be transformed in to gaseous forms. Furthermore, there is a potential atmospheric source of nitrogen to the sea, but this is not considered in this remote region. 


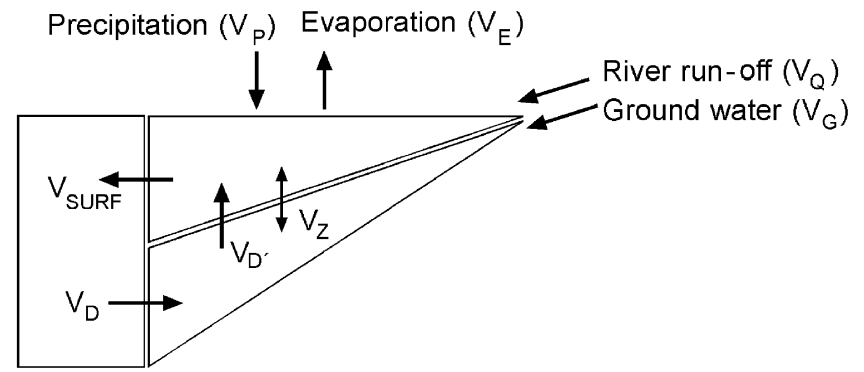

Fig. 4. Schematic illustration of water fluxes in the two-layered coastal system.

Other processes than primary production might impact the DIP concentration, e.g. particle-water interaction, but these are assumed to be negligible in this evaluation. Information regarding different processes and their magnitude can be obtained by comparing DIP, DIN and DIC budgets and stoichiometric calculations.

To compute the budgets of the elements of interest the individual fluxes are needed, which follow the equations:

$Q_{Q}^{D I P}=D I P_{Q} V_{Q}$

$Q_{G}^{D I P}=D I P_{G} V_{G}$,

$Q_{D}^{D I P}=D I P_{\text {Ocean }-D} V_{D}$,

$Q_{D^{\prime}}^{D I P}=D I P_{\text {Shelf }-D} V_{D^{\prime}}$

$Q_{Z}^{D I P}=V_{Z}\left(D I P_{\text {Shelf }-D}-D I P_{\text {Shelf }-S}\right)$,

$Q_{S}^{D I P}=D I P_{\text {Shelf }-S} V_{S}$,

where $D I P_{X}$ stands for the dissolved phosphate concentration in the respective source. The equations to compute the DIN and DIC fluxes are similar, but instead use the concentrations of DIN and DIC. Furthermore, they also have a contribution in the precipitation, as illustrated for DIN in Eq. (15).

$Q_{P}^{D I N}=D I N_{P} V_{P}$.

The net flux out of the shelf system, the surface layer, and the deep layer follow Eqs. (16-18), respectively, where $X$ denotes the constituents. Note that in the net flux computation of DIP the flux by precipitation equals zero.

$\Delta D I X_{\text {Shelf }}=-\left(Q_{P}^{D I X}+Q_{Q}^{D I X}+Q_{G}^{D I X}+Q_{D}^{D I X}-Q_{S}^{D I X}\right)$,

$$
\begin{aligned}
\Delta D I X_{\text {Shelf }-S}=- & \left(Q_{P}^{D I X}+Q_{Q}^{D I X}+Q_{G}^{D I X}+Q_{D^{\prime}}^{D I X}\right. \\
& \left.+Q_{Z}^{D I X}-Q_{S}^{D I X}\right) \\
\Delta D I X_{\text {Shelf }-D}=- & \left(Q_{D}^{D I X}-Q_{D^{\prime}}^{D I X}-Q_{Z}^{D I X}\right) .
\end{aligned}
$$

If an element is conservative, the net flux equals zero. The non-conservative behaviour of phosphate is mainly a result of biological primary production and decay of organic matter. (Other processes, e.g. interaction with particles are not considered, which might be relevant especially in the river plumes.) The biological primary production and decay of organic matter also affect the nitrate and DIC concentrations, but in addition other processes have significant impact on these constituents. Nitrate is used as electron acceptor when organic matter decays in low oxygen environment (denitrification), and DIC is affected by air-sea gas exchange. The net biological metabolism $[p-d]$ (production minus decay) can be calculated as

$[p-d]=-\Delta D I P r_{C / P}$,

where $-\triangle D I P$ equals the observed consumption of phosphate and $r_{C / P}$ is the ratio of carbon to phosphorus in organic matter (e.g. Redfield et al., 1963). The loss of nitrate by denitrification can be represented by the difference in the expected consumption of nitrate and the observed nitrate consumption $(-\Delta D I N)$. The first can be computed from the observed phosphate consumption multiplied by the N:P ratio in organic matter, according to $-\Delta D I N \quad r_{\mathrm{N} / \mathrm{P}}$. Hence, the loss of nitrate by denitrification, Dnit, is expressed by Eq. (20).

Dit $=\Delta D I P r_{N / P}-\Delta D I N$.

The exchange of $\mathrm{CO}_{2}$ between the ocean and atmosphere can be evaluated from the sum of DIC fluxes, according to Eq. (21), if steady state is assumed.

$F_{C}^{A D V}+F_{C}^{B I O}+F_{C}^{a i r-s e a}=0$. 
$F_{C}{ }^{A D V}$ is the sum of fluxes of DIC with currents, river runoff, etc, $F_{C}{ }^{B I O}$ is the net consumption of DIC by biological processes (production minus decay), and $F_{C}$ air-sea is the $\mathrm{CO}_{2}$ air-sea flux. As the $F_{C}^{A D V}=-\triangle D I C$ and $F_{C}^{B I O}=[p-d]=$ $-\triangle D I P r_{C / P}$ Eq. (21) can be rewritten to

$F_{C}^{a i r-s e a}=\Delta D I C+\Delta D I P r_{C / P}$.

The stoichiometric ratios of $\mathrm{N}: \mathrm{P}$ and $\mathrm{C}: \mathrm{P}$ used are 16:1 and 106:1, according to Redfield et al. (1963).

\section{Results and discussion}

\subsection{Inorganic carbon and nutrient fluxes}

This section presents the DIC and nutrient fluxes (phosphate and nitrate) in the Laptev Sea Shelf and western part of the East-Siberian Sea Shelf in the summer (from July to September) of 1994 (Figs. 5 and 6). The total influx of nutrient and DIC to the Laptev Sea Self from land in summer is very extensive, $\quad 0.56 \times 10^{6} \mathrm{~mol} \mathrm{~d}^{-1}$ of phosphate, $2.7 \times 10^{6} \mathrm{~mol} \mathrm{~d}^{-1}$ of nitrate and $1120 \times 10^{6} \mathrm{~mol} \mathrm{~d}^{-1}$ of DIC. However, the influx to the Laptev Sea Shelf from the open ocean is much larger than the total influx from the land. It is 4.5 times more for phosphate, 7.7 times more for nitrate and 5.4 times more for DIC (Fig. 5).

The river runoff into the East-Siberian Sea is less than the one into the Laptev Sea as is the fluxes of DIC and nutrient from land and the open ocean. The exception is the flux of nitrate with river runoff, which is larger because the concentration of nitrate is higher in the Indigirka and Kolyma rivers (approximately $3 \mu \mathrm{mol} \mathrm{kg}^{-1}$ ) compared to the Lena river $\left(1.4 \mu \mathrm{mol} \mathrm{kg}^{-1}\right)$ (Bryzgalo and Ivanov, 2000; Gordeev et al., 1999). The influx from land into the East Siberian Sea is $0.33 \times 10^{6} \mathrm{mold}^{-1}$ of phosphate, $3.6 \times 10^{6} \mathrm{mold}^{-1}$ of nitrate and $600 \times 10^{6} \mathrm{mold}^{-1}$ of DIC. The flux of nutrient and DIC from the central Arctic Ocean into the EastSiberian Sea Shelf is larger than the flux from land, equalling about $1 \times 10^{6} \mathrm{mold}^{-1}, 8 \times 10^{6} \mathrm{~mol} \mathrm{~d}^{-1}$ and $2400 \times 10^{6} \mathrm{mold}^{-1}$, for DIP, DIN and DIC, respectively. The balance of DIC and nutrient, water-atmosphere exchange of $\mathrm{CO}_{2}$ and calculation of system metabolism on the shelf are shown in Table 3.

The results of the budget calculations of DIC and nutrients illustrate that the Laptev Sea Shelf and western part of the East-Siberian Sea Shelf are different during the summer season. The surface layers of these regions are net autotrophic and acts as a net sink of nutrient $(\triangle D I P$ and $\triangle D I N<0$; $[p-d]>0)$. The bottom layers are a net producer of phosphate $(\triangle D I P>0)$ and a net sink of nitrate in summer. But the total budget shows that the Laptev Sea Shelf is net autotrophic $([p-d]>0)$ and western part of the East-Siberian Sea Shelf is net heterotrophic $([p-d]<0)$. All regions are weak net denitrifying systems (Dnit $>0)$.

The balance of DIC shows that the Laptev Sea Shelf is a net producer of DIC while the western part of East-Siberian Sea (excluding the bottom layer) is a net sink of DIC. This is without considering the air-sea flux of $\mathrm{CO}_{2}$. The computed air-sea flux shows a similar pattern, where the Laptev Sea Shelf takes up $\mathrm{CO}_{2}$ from atmosphere

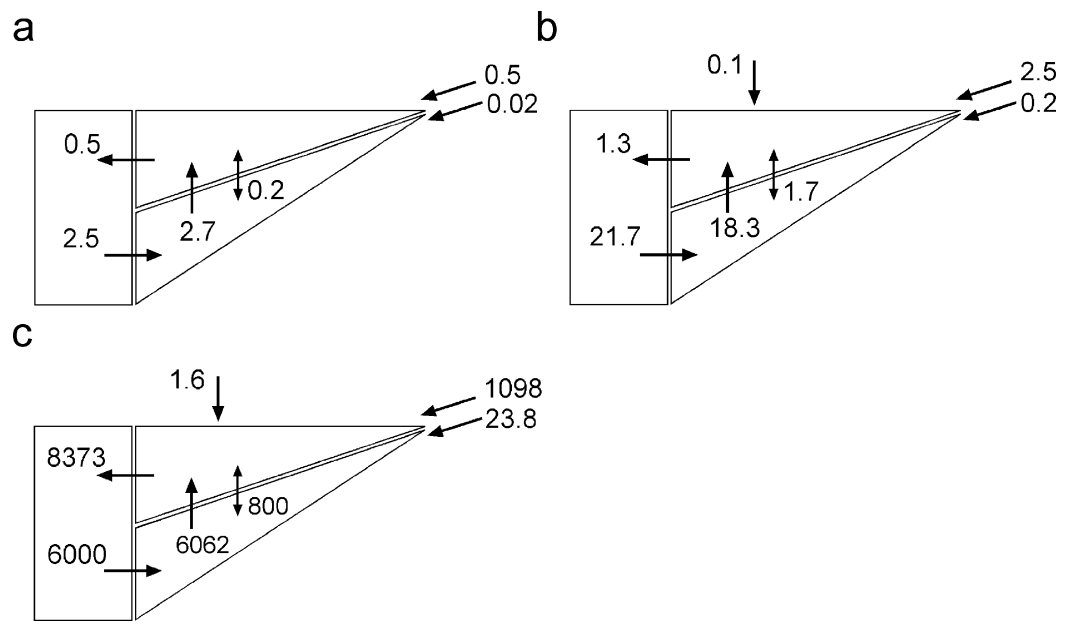

Fig. 5. The fluxes of phosphate (a), nitrate (b) and inorganic carbon (c) in the Laptev Sea Shelf in the summer of $1994\left(10^{6} \mathrm{mold}^{-1}\right)$. 
a

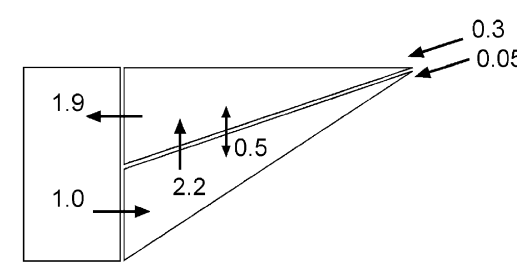

c

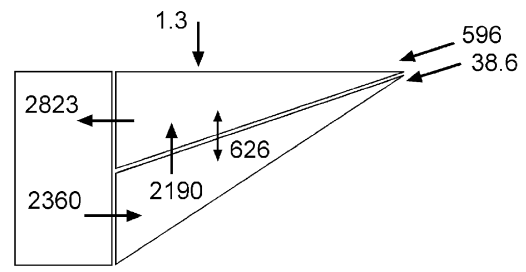

b

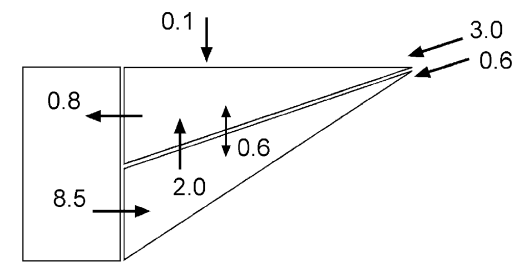

Fig. 6. The fluxes of phosphate (a) and nitrate (b) and flux of inorganic carbon (c) in the summer of 1994 in western part of the EastSiberian Sea Shelf $\left(10^{6} \mathrm{~mol} \mathrm{~d}^{-1}\right)$.

Table 3

The balance of dissolved inorganic carbon, phosphate and nitrate $\left(10^{6} \mathrm{~mol} \mathrm{~d}^{-1}\right)$ and systems metabolism $\left(\mathrm{mmolm}^{-2} \mathrm{~d}^{-1}\right)$ during summer in the Laptev Sea Shelf and western part of the EastSiberian Sea Shelf

\begin{tabular}{|c|c|c|c|}
\hline & & $\begin{array}{l}\text { The Laptev } \\
\text { Sea Shelf }\end{array}$ & $\begin{array}{l}\text { The East-Siberian } \\
\text { Sea Shelf }\end{array}$ \\
\hline \multicolumn{4}{|c|}{$10^{6} \mathrm{~mol} \mathrm{~d}^{-1}$} \\
\hline \multirow[t]{3}{*}{$\triangle D I P$} & Surface & -3.0 & -1.1 \\
\hline & Deep & 0.5 & 1.7 \\
\hline & System & -2.5 & 0.5 \\
\hline \multirow[t]{3}{*}{$\Delta D I N$} & Surface & -21.5 & -5.5 \\
\hline & Deep & -1.7 & -5.9 \\
\hline & System & -23.2 & -11.4 \\
\hline \multirow[t]{3}{*}{$\triangle D I C$} & Surface & 1111 & -258 \\
\hline & Deep & 137 & 84 \\
\hline & System & 1249 & -173 \\
\hline \multicolumn{4}{|c|}{$\mathrm{mmol} \mathrm{m}^{-2} \mathrm{~d}^{-1}$} \\
\hline \multirow[t]{3}{*}[p-d]{} & Surface & 0.68 & 0.30 \\
\hline & Deep & -0.11 & -0.45 \\
\hline & System & 0.56 & -0.15 \\
\hline \multirow[t]{3}{*}{ Dnit } & Surface & 0.03 & 0.01 \\
\hline & Deep & 0.01 & 0.02 \\
\hline & System & 0.04 & 0.03 \\
\hline \multirow[t]{3}{*}{$F_{C}^{a i r-s e a}$} & Surface & 1.7 & -1.0 \\
\hline & Deep & 0.4 & 0.7 \\
\hline & System & 2.1 & -0.3 \\
\hline
\end{tabular}

Note that negative $\Delta D I X$ fluxes are into of the specific box, while the computed air-sea fluxes of carbon have positive signs into the sea.

$\left(F_{C}{ }^{a i r-s e a}>0\right) \quad$ (approximately flux is $2.1 \mathrm{mmol} \mathrm{m}^{-2} \mathrm{~d}^{-1}$ ), while the western part of the East-Siberian Sea Shelf have a small loss of $\mathrm{CO}_{2}$ to the atmosphere $\left(F_{C}{ }^{\text {air-sea }}<0\right)$ (approximately, flux is $\left.-0.3 \mathrm{mmol} \mathrm{m}^{-2} \mathrm{~d}^{-1}\right)$. The latter is likely a result of decreased solubility caused by warming of the surface water. Also the surface water of the Laptev Sea gets warmer during summer, but the draw down of $p \mathrm{CO}_{2}$ by photosynthetic activity more than compensate for the resulting decrease in solubility. Photosynthesis is larger in the Laptev Sea compared to the East-Siberian Sea (The Soviet Arctic, 1970).

\subsection{Space variability of DIC and nutrient fluxes and system metabolism in the Laptev Sea}

The special variability within the Laptev Sea Self was investigated by evaluating data from three regions, the Buor-Khaya bay, the Buor-Khaya and Yana bays, and the whole Laptev Sea Shelf (Fig. 1). The concentration of the chemical constituents used where obtained during the international TUNDRA and TRANSDRIFT expeditions in 1994. These and other relevant data are given in the Table 1 . The Buor-Khaya bay has the smallest area and is shallower then the other regions, but it receives about $70 \%$ of the total river runoff that enters the Laptev Sea, resulting in the lowest salinity. The strength of precipitation and evaporation within these regions are proportionate to their areas. The Laptev Sea Shelf has the highest salinities because of mixing along the extensive open boundary to Arctic Ocean, and by the inflow of water through the Vilkitsky Strait. The results of the computations for the three regions are given in Table 4 and Fig. 7.

As shown in Table 4 the balance of DIP and DIN in the Buor-Khaya bay area and Buor-Khaya and 
Yana bays area are similar, while the Laptev Sea Shelf have a stronger net inflow of DIP (more negative $\triangle D I P$ ) and less strong net inflow of DIN (less negative $\triangle D I N$ ) compared to the smaller regions. However, all parts of Laptev Sea Shelf have negative $\triangle D I P$ and $\triangle D I N$ and thus act as net sinks of these constituents. The balance of DIC is positive in all areas and increases proportional of their areas. This balance does not include the air-sea flux, which likely is the cause of the positive balance.

When only studying the summer season it is difficult to evaluate the balance of these constituents in the surface and bottom layers, respectively, and the cause of these observations. There are at least two reasons for this: one is that the nutrient concentrations are very low in the surface layer (Table 1) giving a large relative error in the balance for a small error in concentration. The other reason is that organic matter produced during the spring season could contribute to the dissolved pool in the summer, but in ratios different from that of the classic Redfield-Ketchum-Richard (1963). Nevertheless, all three areas have much more negative $\triangle D I P$ and $\triangle D I N$ in the surface layer compared to the bottom layer, supporting a primary production sink. Furthermore, the bottom layers of the BuorKhaya and Yana bays area and the Laptev Sea Shelf have positive $\triangle D I P$, giving that these areas are net producer of phosphate. The likely explanation to this difference is that the Buor-Khaya bay is very shallow (bottom depth $<10 \mathrm{~m}$ ), with possibility of light conditions supporting primary production even in the bottom layer. The Buor-Khaya and Yana bays area also have positive $\triangle D I N$ in the bottom layer and thus is a net producer of nitrate. This area has very special bottom topography with a lot of bottom depressions and stagnant water masses with low oxygen and high nutrient concentrations (Pivovarov, 2000; Nitishinsky et al., 2003).

The summer net primary production $(p-r)$ decreases significantly from the small area of the Buor-Khaya bay to the larger Buor-Khaya and Yana bays area and into the largest area of the Laptev Sea Shelf (Table 4). This pattern is likely a result of the high supply of nutrients from the Lena River to the small volume of the Buor-Khaya bay compared to the relative nutrient supply to the other regions. The net primary production is also concentrated to the surface layers, as is obvious from the $\triangle D I P$ balances. The obtained net primary production rates are of the same order as reported

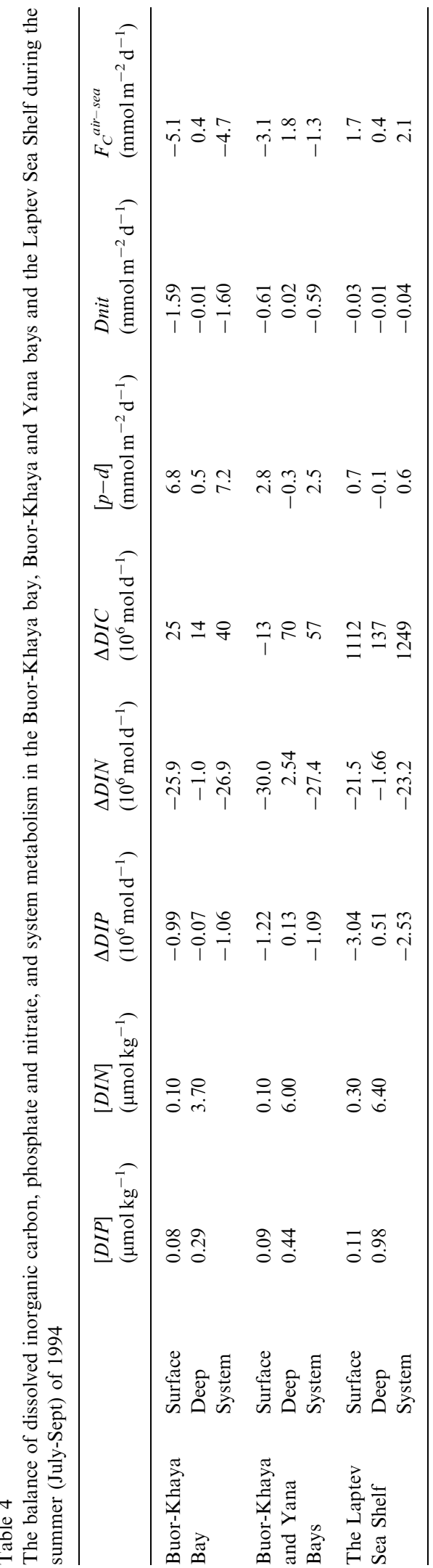


a

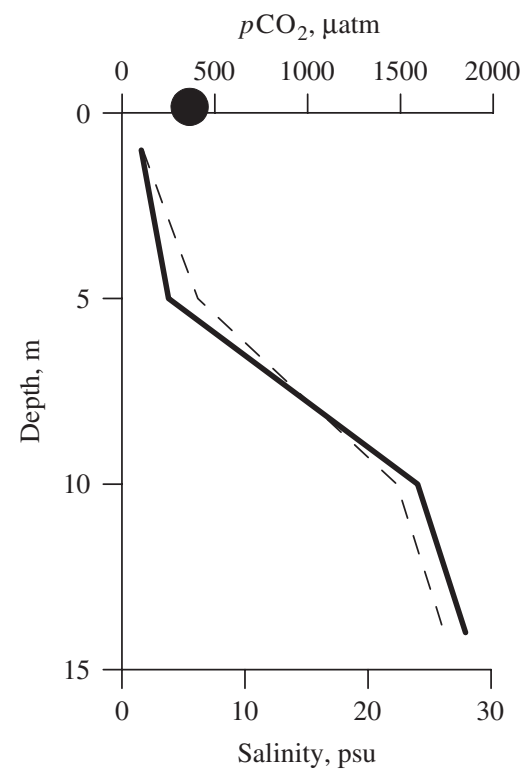

b

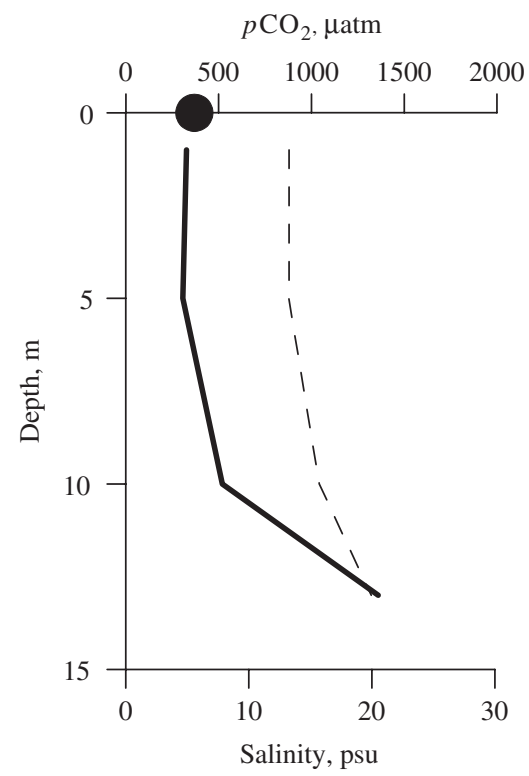

Fig. 7. The vertical distribution of $p \mathrm{CO}_{2}$ (solid line) and salinity (dotted line) in the Buor-Khaya (a) and Yana (b) bays in summer 1994 . Data from TUNDRA expedition (Olsson and Anderson, 1997). The points represent the atmospheric $p \mathrm{CO}_{2}$.

primary production rates in the Laptev Sea (Tuschling, 2000; Gleitz and Grossmann, 1997), which were $75-640 \mathrm{mg} \mathrm{C} \mathrm{m}^{-3} \mathrm{~d}^{-1}$ in the Buor-Khaya bay, $40-90 \mathrm{mg} \mathrm{C} \mathrm{m}^{-3} \mathrm{~d}^{-1}$ in the eastern part of the Laptev Sea Shelf and Yana bay, $24-41 \mathrm{mg} \mathrm{Cm}^{-3} \mathrm{~d}^{-1}$ on the western part of the Laptev Sea Shelf, and $115-154 \mathrm{mg} \mathrm{C} \mathrm{m}^{-3} \mathrm{~d}^{-1}$ in the north part of the Laptev Sea on the continental slope.

The surface water flux of nutrients from the coastal areas is an important supply to the central part of the Laptev Sea Shelf (Stein and Fahl, 2004). These nutrients can either have a direct runoff contribution or gone through the cycle of primary production, sedimentation of organic matter, mineralization of organic matter at the sediment surface, release to the bottom water, followed by mixing up into the surface layer of the shallow coastal areas.

The summer air-sea $\mathrm{CO}_{2}$ flux is negative in the Buor-Khaya and Yana bays and in the Buor-Khaya bay, with fluxes of -1.3 and $-4.7 \mathrm{mmol} \mathrm{m}^{-2} \mathrm{~d}^{-1}$, respectively. However, integrated over the Laptev Sea Shelf it is positive, with a flux of $2.1 \mathrm{mmol} \mathrm{m}^{-2} \mathrm{~d}^{-1}$. This difference likely depends on several factors, like different phytoplankton activity in the central part of the Laptev Sea Shelf and in bays (Tuschling, 2000) and high concentration of dissolved and particular organic matter
(DOM and POM) in river water (Gordeev et al., 1999; Romankevich and Vetrov, 2001). Both DOM and POM can be converted to $\mathrm{CO}_{2}$ through microbial activity, and thus increase $p \mathrm{CO}_{2}$ in the water.

Fig. 7 shows the vertical distribution of $p \mathrm{CO}_{2}$ in the Buor-Khaya and Yana bays and at the air-sea boundary (Olsson and Anderson, 1997). The profiles show that the surface layer is undersaturated (more so in the Buor-Khaya bay than the Yana bay) compared to the atmosphere, but with increasing $p \mathrm{CO}_{2}$ towards the bottom, where a very high over-saturation is observed. This is valid even in these shallow bays area where mixing is expected to play an important role. Mixing of dissolved $\mathrm{CO}_{2}$ from the bottom layer to the surface will increase the $p \mathrm{CO}_{2}$ and thus contribute to a negative $\mathrm{CO}_{2}$ air-sea flux.

\subsection{Inter-annual variability of carbon and nutrient fluxes on the Laptev Sea Shelf}

The inter-annual variability of the phosphate balance $(\triangle D I P)$ and differences of net primary production $[p-r]$ for the 16 summer seasons from 1963 to 1999 in the Laptev Sea Shelf based on the data of Table 2 are presented in Table 5. For the 
whole period $\triangle D I P$ is negative and $[p-r]$ positive, with average $\triangle D I P$ being $-881 \times 10^{3} \mathrm{~mol} \mathrm{~d}^{-1}$ in the Buor-Khaya bay, $-1032 \times 10^{3} \mathrm{~mol} \mathrm{~d}^{-1}$ in the area of Buor-Khaya and Yana bays and $-2351 \times 10^{3} \mathrm{~mol} \mathrm{~d}^{-1}$ on the Laptev Sea Shelf (Table 5). Correspondingly, the average net primary production $[p-r]$ is $5.98,2.36$ and $0.52 \mathrm{mmol} \mathrm{m}^{-2} \mathrm{~d}^{-1}$ for the Buor-Khaya bay, area of Buor-Khaya and Yana bays and the Laptev Sea Shelf, respectively. The regional pattern over this period is much the same as for the year 1994 (compare Table 5), the year when a significantly larger data set was available.

Both the phosphate balance and the net primary production show high temporal variability over the period. The variability over the whole period, expressed as standard deviation, decreases with the aerial coverage, from $31 \%$ for the Buor-Khaya bay, to $30 \%$ for the Buor-Khaya and Yana bays, and $23 \%$ for the Laptev Sea Shelf, both for $\triangle D I P$ and $[p-r]$.

Even if the variability is significant there is a significant trend in $\triangle D I P$ of $-16.9 \times 10^{3} \mathrm{~mol} \mathrm{~d}^{-1}$ per year with an $R^{2}=0.54$ (linear fit of the data in Fig. 8a) in the Buor-Khaya bay. The trend is less pronounced in the Buor-Khaya and Yana bays from where fewer data is available (Fig. 8b), and for the Laptev Sea Shelf where the last years of the 1990s have an increasing trend instead of a decreasing as for the Buor-Khaya bay (Fig. 8c). Over the same time period there is an increasing trend in the AO index (Fig. 8d), which is paralleled with an increasing trend in the river discharge from Siberia (Peterson et al., 2002) and also more locally from the Lena river (Fig. 8e). It is plausible that there is a link from an increasing AO index resulting in increased precipitation over the Siberian river drainage basins to an increased discharge and thereby an increased supply of nutrients by the rivers to an increased net primary production (more negative $\Delta \mathrm{DIP}$ ). However, this is only one of several possible scenarios.

\subsection{Comparison with other Shelf Seas}

Our computed air-sea $\mathrm{CO}_{2}$ fluxes in the Laptev Sea Shelf are compared to estimates from other Arctic Ocean areas in Table 6. It is difficult to make direct quantitative comparisons as our values only represent the summer season, while the others cover the whole year, including the seasons of dominating decay processes. Nevertheless the estimate for the Laptev Sea Shelf are of the same order as that of the

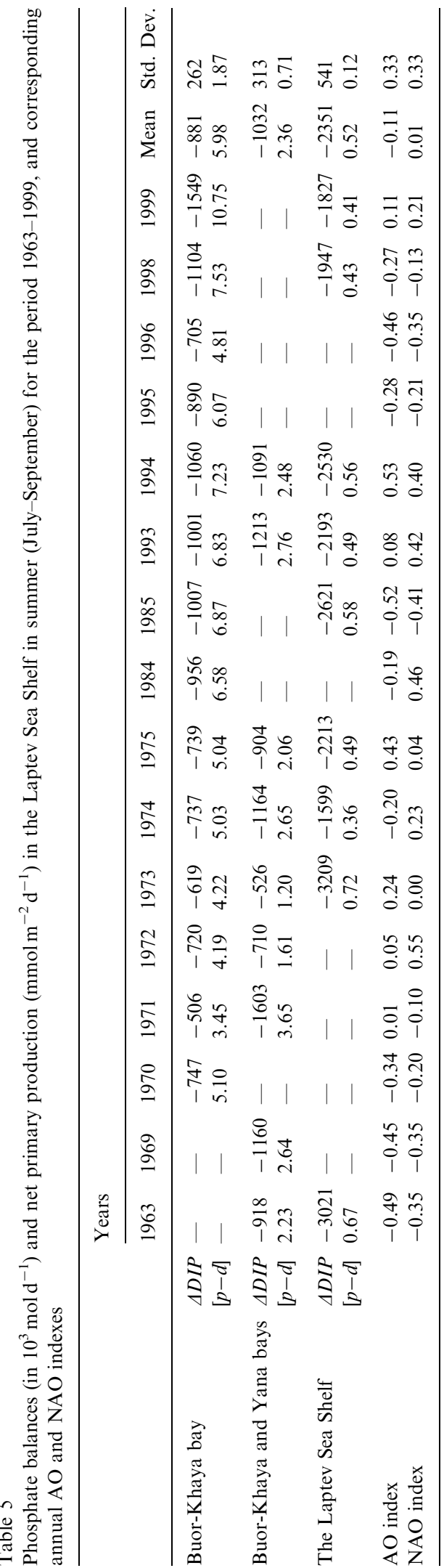




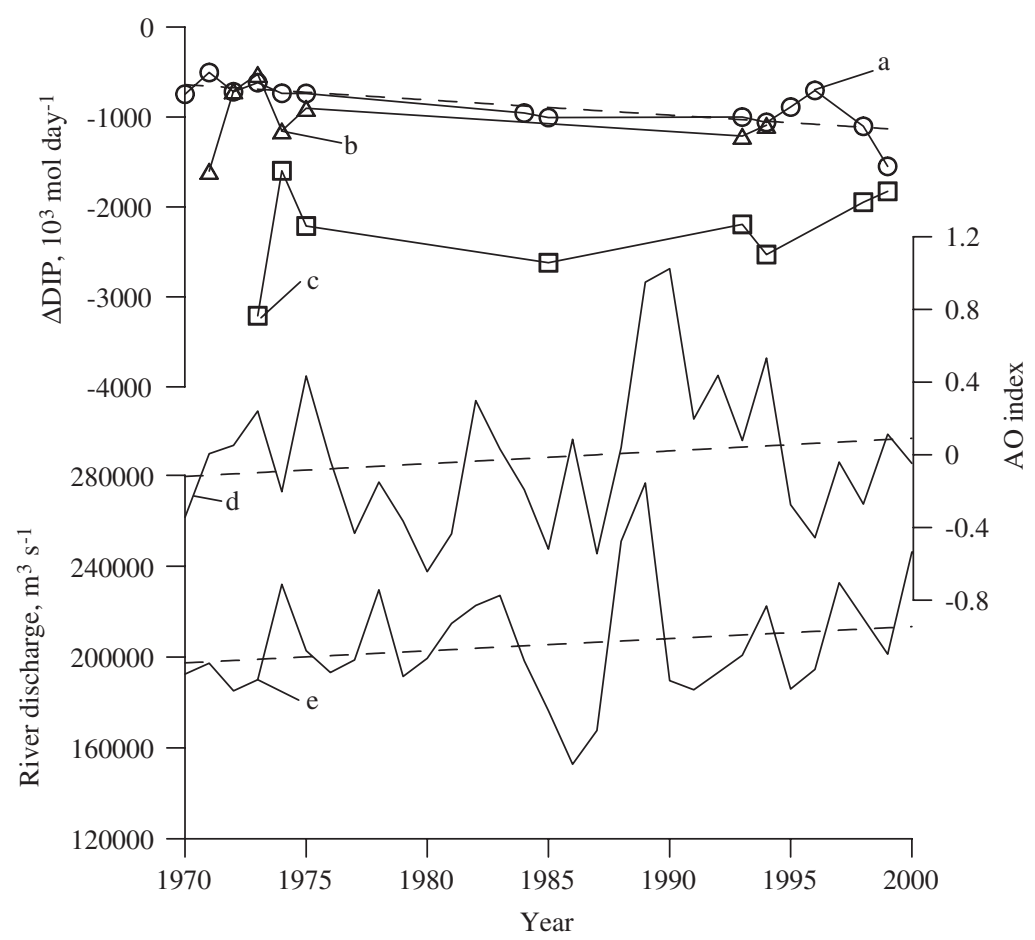

Fig. 8. $\triangle \mathrm{DIP}\left(10^{6} \mathrm{mold}^{-1}\right)$ in the Buor-Khaya bay (a), in the area of Buor-Khaya and Yana bays (b), on the Laptev Sea Shelf (c), annual AO index (d) (http://www.cpc.ncep.noaa.gov) and annual River discharge $\left(\mathrm{m}^{3} \mathrm{~s}^{-1}\right.$ ) of Lana River on the Station Kysyr (e) (http:// www.r-arcticnet.sr.unh.edu) from 1970 till 2000. The dashed lines equals the best fit to the trends with the lines being for (a) $\Delta D I P=-16.9 \times$ Year $+32702\left(R^{2}=0.54\right),(\mathrm{d}) \mathrm{AO}=0.007 \times$ Year-13.92 $\left(R^{2}=0.025\right)$, and $(\mathrm{e}) \mathrm{RD}=532 \times \mathrm{Year}-850792\left(R^{2}=0.035\right)$.

Table 6

The air-sea $\mathrm{CO}_{2}$ fluxes $\left(\mathrm{mmol} \mathrm{m}^{-2} \mathrm{~d}^{-1}\right)$ in different parts of Arctic Ocean

\begin{tabular}{llcl}
\hline Area & Season & $\begin{array}{l}F_{C}{ }^{\text {air-sea }} \\
\left(\mathrm{mmol} \mathrm{m}^{-2} \mathrm{~d}^{-1}\right)\end{array}$ & References \\
\hline The Arctic Ocean & Annual & 0.4 & Anderson et al. (1998) \\
The Barents Sea & Annual & 1.5 & Fransson et al. (2001) \\
The Laptev Sea Shelf & Summer & 2.1 & Our calculations \\
The East Siberian Sea Shelf & Summer & -0.3 & Our calculations \\
The Greenland Sea & Annual & 2.9 & Anderson et al. (2000) \\
The Chukchi and Bering Seas & Annual & 7.1 & Katlin and Anderson (2005) \\
\hline
\end{tabular}

Barents Sea, while it is significantly lower than that of the Chukchi and Bering Seas. The latter is likely a result of the high nutrient supply to this region from the northern Pacific Ocean. Also the air-sea uptake of $\mathrm{CO}_{2}$ in Greenland Sea is larger than that of the Laptev Sea Shelf, but this is more likely caused by cooling of the surface water that supplies the Greenland Sea, resulting in higher solubility and thus an increase in the air-sea driving force. The low $\mathrm{CO}_{2}$ uptake in the central Arctic Ocean reflects the ice cover, which hampers the exchange between the ocean and atmosphere. The only region with a negative air-sea $\mathrm{CO}_{2}$ flux is the East Siberian Sea Shelf and this could be a result of dominant decay of organic matter, both of marine and terrestrial origin. Negative air-sea flux of $\mathrm{CO}_{2}$ during summer condition has been reported from other shelf seas, like the northern part of the North Sea $\left(-1.7 \mathrm{mmol} \mathrm{m}^{-2} \mathrm{~d}^{-1}\right)$ also (Bozec et al., 2005).

\section{Summary and conclusions}

A number of factors, like bottom topography, river runoff, exchange with surrounding seas, wind field, 
etc, effects the flux of dissolved inorganic carbon and nutrients in Arctic shelf seas. During the summer the surface layers in the Laptev is autotrophic and acts as a net sink of nutrients. The total nutrient budget shows that the East-Siberian Sea Shelf is a heterotrophic system in summer. Both areas are weak net denitrifying systems.

Computed summer air-sea $\mathrm{CO}_{2}$ fluxes gives that the Laptev Sea Shelf takes up $\mathrm{CO}_{2}$ from atmosphere while the western part of the East-Siberian Sea Shelf have a small loss of $\mathrm{CO}_{2}$ to the atmosphere. The $\mathrm{CO}_{2}$ uptake from atmosphere into the Laptev Sea Shelf is $2.1 \mathrm{mmol} \mathrm{m}^{-2} \mathrm{~d}^{-1}$. This flux is in the same order as air-sea $\mathrm{CO}_{2}$ fluxes in other Arctic shelf seas dominated by seawater of Atlantic origin. The $\mathrm{CO}_{2}$ flux in the East-Siberian Sea Shelf is $-0.3 \mathrm{mmol} \mathrm{m}^{-2} \mathrm{~d}^{-1}$.

While the total Laptev Sea Shelf takes up $\mathrm{CO}_{2}$ from the atmosphere it is different in smaller areas of this shelf sea where the shallow water depth amplify the effect by bottom topography and the river runoff have a higher influence. The bottom layer of Buor-Khaya bay acts as a net sink of nutrients, while the bottom layer of the Buor-Khaya and Yana bays is a small net producer of nutrients. When the whole water column is considered, both areas act as a net sink of nutrient and are thereby net autotrophic systems. The calculated air-sea $\mathrm{CO}_{2}$ fluxes resulted in that these small coastal ecosystems lose $\mathrm{CO}_{2}$ to the atmosphere in summer, with the air-sea $\mathrm{CO}_{2}$ flux being -4.7 and $-1.3 \mathrm{mmol} \mathrm{m}^{-2} \mathrm{~d}^{-1}$ in the Buor-Khaya bay and the area of Buor-Khaya and Yana bays, respectively.

Calculated phosphate fluxes showed significant trends with time in the different parts of the Laptev Sea Shelf, with the maximum changes in BuorKhaya bay, where the decrease in the period 1970-99 is $-16.9 \times 10^{3} \mathrm{~mol} \mathrm{~d}^{-1}$ year $^{-1}$. However, this trend is an average of a highly variable system, where the phosphate fluxes are different from year to year. The mean ( \pm standard deviation) in phosphate fluxes are $-881( \pm 262) \times 10^{3},-1032$ $( \pm 313) \times 10^{3}$ and $-2351( \pm 514) \times 10^{3} \mathrm{mold}^{-1}$, in the areas of Buor-Khaya bay, Buor-Khaya and Yana bays and Laptev Sea Shelf, respectively.

\section{Acknowledgements}

We gratefully acknowledge the support by the Swedish research Council, by the Royal Swedish Academy of Science and by Otto Schmidt Laboratory. The data used in this work has been gathered by a number of individuals, whose efforts are much appreciated.

\section{References}

Anderson, L.G., Olsson, K., Chierici, M., 1998. A carbon budget for the Arctic Ocean. Global Biogeochemical Cycles 12, 455-465.

Anderson, L.G., Drange, H., Chierici, M., Fransson, A., Johannessen, T., Skjelvan, I., Rey, F., 2000. Annual variability of carbon flux in the upper Greenland Sea, as evaluated from measured data and a box model. Tellus 52B, 1013-1024.

Baskakov, G.A., Kosheleva, G.Y., Zhukov, V.I., 1999. Nonperiodical flow in the south-eastern part of the Laptev Sea in summer. Proceeding of AARI 442, 84-99 (in Russian).

Bozec, Y., Tomas, H., Elkalay, K., de Baar, H.J.W., 2005. The continental shelf pump for $\mathrm{CO}_{2}$ in the North Seaevidence from summer observation. Marine Chemistry 93 131-147.

Bryzgalo, V.A., Ivanov, V.V., 2000. The inflow of dissolved matter through river runoff into the Russia Arctic seas. Annual and seasonal variability. Ecological Chemistry 9 (2), 76-89 (in Russian).

Cavalieri, D.J., Gloerson, P., Parkingson, C.L., Comiso, J.C., Zwally, H.Z., 1997. Observed hemispheric asymmetry in global sea ice change. Science 278, 1104-1106.

Colony, R., Nikiforov, Y.G., Pivovarov, S.V., Pokrovsky, J.M., Priamikov, S.M., Timokhov, L.A., 2002. Data base and atlas of hydrochemistry of the Arctic Ocean. Ocean Science Meeting, Honolulu, Hawaii, USA. OS41M-06.

Danilov, A.I., Ivanov, V.V., Pryamikov, S.M., Timokhov, L.A., 1994. Environmental complex of the Laptev and EastSiberian seas region. In: Scientific Results of the LAPEX-93 (TRANSDRIFT-I) Expedition. Gidrometeoizdat, St. Petersburg, pp. 32-45 (in Russian).

David, L.T., San Diego-McGlone, Crossland, C.J., Smith, S.V., 2000. LOICZ Biogeochemical Budgeting Procedure: A Tutorial Pamphlet. LOICZ-IPO. Texel, The Netherlands, 29p.

Fransson, A., Chierici, M., Anderson, L.G., Bussman, I., Kattner, G., Jones, E.P., Swift, J.H., 2001. The importance of shelf processes for the modification of chemical constituents in the waters of the eastern Arctic Ocean: implication for carbon flux. Continental Shelf Research 21, 225-242.

Gleitz, M., Grossmann, S., 1997. Phytoplankton primary production and bacterial production. Berichte Polarforschung 226, 92-94.

Gordeev, V.V., Dgamalov, R.G., Zekcep, I.S., Julidov, W.W., Brizgalo, W.A., 1999. Estimations of inflow of nutrient with river runoff and ground water in Marginal Seas of Russian Arctic. Water Source 26 (2), 206-211 (in Russian).

Gordon, Jr.,D.C., Boudreau, P.R., Mann, K.H., Ong, J.-E., Silvert, W.L., Smith, S.V., Wattayakorn, G., Wulff, F., Yanagi, T., 1996. LOICZ biogeochemical modelling guidelines. LOICZ Reports and Studies 5, 1-96.

Ipatov, A.B., Yakovlev, A.W., 1999. The scheme of water circulation in the Laptev Sea in summer obtained on the basis of analysis of full-scale data. Proceeding of AARI 442, 100-107 (in Russian).

Johannessen, O.M., Miles, M., Bjørgo, E., 1995. The Arctic's shrinking sea ice. Nature 376, 126-127. 
Katlin, S., Anderson, L.G., 2005. Uptake of atmospheric carbon dioxide in Arctic Shelf seas: evaluation of the relative importance of processes that influence $p \mathrm{CO}_{2}$ in water transport over the Bering-Chukchi Seas Shelf. Marine Chemistry 94, 67-79.

Nikiforov, E.G., Shpaicher, A.O., 1980. Features of the Formation of Hydrological Regime Large-scale Variations in the Arctic Ocean. Gidrometeoizdat, St. Petersburg, 272pp. (in Russian).

Nitishinsky, M., Pivovarov, S., Holemann, J., 2003. Water column structure and interannual variability of hydrochemical parameters at the transect along $75^{\circ} 30^{\prime} \mathrm{N}$ across the Laptev Sea in summer. ACSYS Final Science Conference, St. Petersburg, Russia, p. 121.

Olsson, K., Anderson, L.G., 1997. Input and biogeochemical transformation of dissolved carbon in the Siberian shelf seas. Continental Shelf Research 17, 819-833.

Peterson, B.J., Holmes, R.M., McClelland, J.W., Vorosmarty, C.J., Lammers, R.B., Shiklomanov, A.I., Shiknomanov, I.A., Rahmstor, S., 2002. Increasing river discharge to the Arctic Ocean. Science 298, 2171-2173.

Pivovarov, S.V., 2000. Chemistry Oceanography of the Arctic Seas of Russia. Gidrometeoizdat, St. Petersburg, 88pp. (in Russian).

Pivovarov, S.V., Smagin, V.M., 1995. Distribution of oxygen and nutrients in the Laptev Sea in summer. Reports on Polar Research 176, 135-141.

Redfield, A., Ketchum, B.H., Richards, F.A., 1963. The influence of organisms on the composition of seawater. In: Hill, M.N. (Ed.), The Sea, vol. 2. Inter science, New York, pp. 26-77.

Romankevich, E.A., Vetrov, A.A., 2001. Cycle of Carbon in the Russian Arctic Seas. Nauka, Moskow, 302p.

Rothrock, D.A., Zhang, J., 2005. Arctic Ocean sea ice volume: what explains its recent depletion? Journal Geophysical Research 110, C01002.
Rusanov, V.P., Ykovlev, N.I., Buinevich, A.G., 1979. Hydrochemical regime of the Arctic Ocean. Proceeding of AARI 355, 1-144 (in Russian).

Schlosser, P., Grabitz, D., Fairbanks, R., Bönisch, G., 1994. Arctic river runoff: mean residence time on the shelves and in the halocline. Deep-Sea Research 41 (Part I), 1053-1068.

Sorokin, Y.I., Sorokin, P.Y., Protkova, Y.V., 1993. Primary production and phytoplankton distribution in the Lena River estuary and in the adjacent Laptev Sea area. Proceeding of Academy of Science 333 (4), 22-525 (in Russian).

Stein, R., Fahl, K., 2004. The Laptev Sea: distribution, sources, variability and burial of organic carbon. In: Stein, R., Macdonald, R.W. (Eds.), The Organic Carbon Cycle in the Arctic Ocean. Springer, Berlin, pp. 213-236.

The Atlas of the Arctic, 1985. Moskva, 204pp. (in Russian).

The Soviet Arctic, 1970. Seas and Islands of the Arctic Ocean. Nauka, Moskva, 526pp. (in Russian).

Thiede, J., Timokhov, L., Bauch, H.A., Bolshiyanov, D., Dmitrenko, I., Eicken, H., Fahl, K., Gukov, A., Hölemann, J., Hubberten, H.W., Juterzenka, K.V., Kassens, H., Melles, M., Petryashov, V., Pivovarov, S., Priamikov, S., Rachold, V., Schmid, M., Siegert, C., Spindler, M., Stein, R., Scientific Party, 1999. Dynamics and history of the Laptev Sea and its continental hinterland: a summary. In: Kassens, H., et al. (Eds.), Land-Ocean System in the Siberian Arctic: Dynamics and History. Springer, Berlin, pp. 695-711.

Tuschling, K., 2000. Phytoplankton ecology in the arctic Laptev Sea-a comparison of three seasons. Berichte Polarforschung 347, 1-144 (in German).

Zakharov, V.F., 1996. Sea ice in the climate system. Gidrometeoizdat, St. Petersburg, 214pp. (in Russian). 